\title{
The Impact of Family Business Governance on Organizational Innovation: A Field Study at Family Firms Operating in Yemen
}

\section{Assoc. Prof. Dr. Murad Mohammed Abdullah Al-Nashmi ${ }^{1}$ Dr. Mohammed Ahmed Ali Shujaa Aldeen²}

Received: 29 June 2021

Revised: 14 Jule 2021 Accepted: 19 August 2021

(C) 2021 University of Science and Technology, Yemen. This articlecan be distributed under the terms of the Creative Commons Attribution License, which permits unrestricted use, distribution, and reproduction in any medium, provided the original author and source are credited.

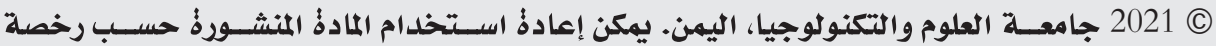
مؤسسة المشاع الإبلاعي شريطة الاستشهاد بالمؤلف والمجلة.

\footnotetext{
${ }^{1}$ Associate Professor of Business Administration, University of Science and Technology, Yemen

${ }^{2}$ Assistant Professor of Business Administration, University of Science and Technology, Yemen

Corresponding author: m.shujaa@ust.edu.ye
} 
The Impact of Family Business Governance on Organizational Innovation: A Field Study at Family Firms Operating in Yemen

\section{Abstract}

This study aims to investigate the impact of family business governance (FBG) on organizational innovation (OIN) in family firms operating in Yemen. The study collected data from 219 family firms, and employed PLS-SEM to test the hypotheses and validate the study model. The results provide evidence of the influence of FBG on OIN in family firms, and that the application of FBG practices promotes better results at the organizational level seen as product innovation and process innovation. The results show that there are significant differences in organizational innovation that can be attributed to the size of the firm, while no differences are found to be attributed to the generation in charge. These findings provide a better understanding of the innovativeness in family firms with respect to the different roles of formal and informal governance structures, and may help business families to develop more effective governance structures out of which more active stewards with more innovative ideas can help trigger better organizational innovation. This paper attempts to update the current knowledge concerning inconsistency of findings in prior studies, and so contributes in updating research opportunities with respect to heterogeneity in family firms.

Keywords: family business governance, family firms, organizational innovation, product and process innovation. 


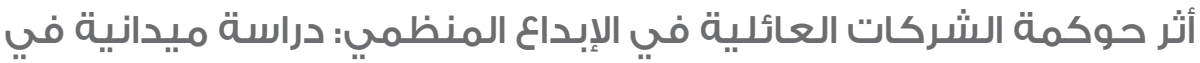

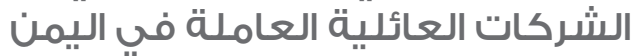

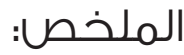

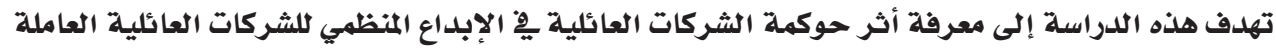

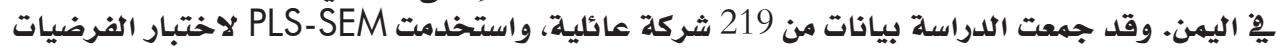

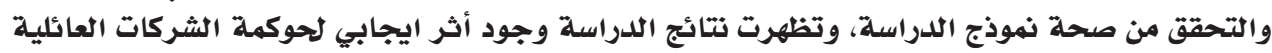

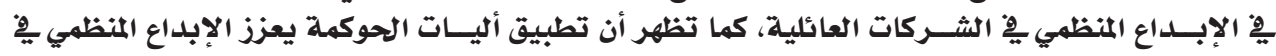

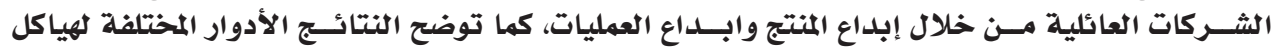

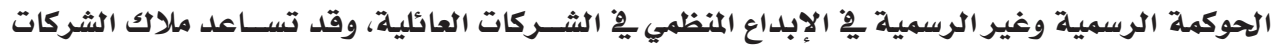

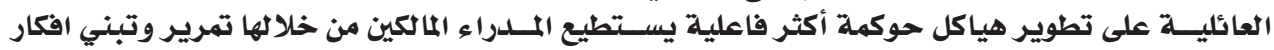

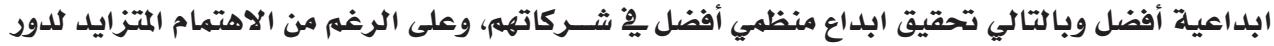

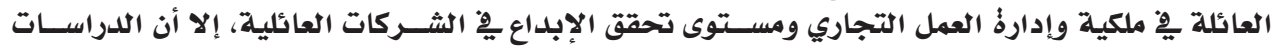

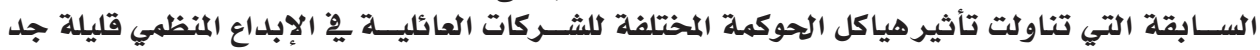

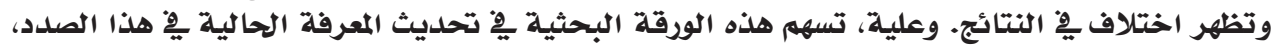

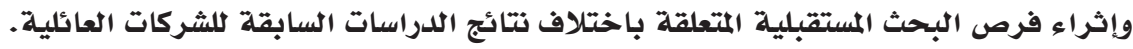
الكلمات المفتاحية : حوكمة الشركات العائلية، الشركات العائلية، الإبلاع المنظمي، إبلداع المنتج، إبلاع العمليات. 


\section{Introduction}

According to Family Firm Institute, a majority of the world's wealth is created by family-owned firms, triggering around $7090 \%$ - of world's Gross Domestic Product (GDP), and up to $85 \%$ of start-ups worldwide are established with family money (Global Data Points, 2017). While family firms account for more than $95 \%$ of the firms in the Arab world, this percentage may increase in Yemen considering the limited number of public shareholding companies due to lack of suitable stock trading environment (Yemen Business Club (YBC), 2016a).

\section{Organizational Innovation in Family Firms}

While organizational innovation as a field of study still receives less attention (Pauget \& Wald, 2018), its concept is considered to be transversal and can be discussed in multiple clusters as a term used to represent any type of innovation within the context of the organization (Alves, Galina, \& Dobelin, 2018). This may explain the inconsistency in literature on organizational innovation not only to its definition, but also relevant antecedents and specific theoretical framework, indicating the wide range of phenomena adopted by authors in addressing organizational innovation (Craig \& Moores, 2006; Damanpour, 1991; Janssen, 2015; Lam, 2004; Stuart, 2000).

While innovation is seen as either "diffusion" or "adoption" of innovations in organization (Damanpour, 1991), organizational innovation can be differentiated as intra-organizational dimension or inter-organizational innovation dimension (Armbrustera, Bikfalvi, Kinkel, \& Lay, 2008),

Lam (2004) finds a rather more complex and multilevel relationship between organization and innovation where variant perspectives attempt to explain organizational innovation including three main strands of the existing literature. First strand relates to organizational structure and design theories; second strand considers organizational cognitive and learning theories; and the third strand focuses on organizational change and adaptation theories. Organizational innovation can also be differentiated in regards to intraorganizational dimension which takes place within the boundary of the organization or inter-organizational innovation dimension which focuses on new structures or procedures handled beyond the organization boundary (Armbrustera et al., 2008). One more approach to study organizational innovation is addressing innovation from different perspectives. For instance, innovation can be addressed as an independent variable, a dependent 
variable, as sources of innovation, as types of innovation, and as innovation climate. Innovation can also be addressed as measurement of innovation in which studies focus on surveys measuring variant aspects of innovation (e.g., innovation behavior, barriers to innovation, adoption of innovation, complexity, outcomes and climate of innovation). Currently well-known surveys are OECD's Oslo Manuals, Community Innovation Surveys (CIS), Policies, Appropriation, and Competitiveness in Europe (PACE), and The Australian Public Service Commission's (APSC) (Demircioglu, 2018).

We use the type of innovation with respect to the definition of organizational innovation (Demircioglu, 2018), where organizational innovation is the introduction of something new, such as a new idea, new product, new process, technology and strategy. Therefore, this study uses product innovation and process innovation as the conceptualization of dimensions for organizational innovation which is also supported by Fu, Liu, Yang, Jiao, and Jin (2020), Frank et al. (2019) and even previously by Bammens, Gils, and Voordeckers (2010) and Llach (2010) who argue that both product innovation and process innovation are among the most commonly used innovation indicators in previous studies related to family firm.

Furthermore, considering the Yemeni context, the use of types of organizational innovation serves the purpose of this study. Yemeni family firms are likely to put more weight on both product innovation needed to meet their customers' urgent needs while bearing in mind their level of income, and process innovation that enhances these firms' efficiency, so far needed to cope with difficulties caused by the current war in Yemen, and accordingly maintain their businesses.

\section{Family Business Governance}

The governance mechanisms in family firms vary in types and significance as compared with corporate governance structures adopted by nonfamily-held firms. Such difference lies in the family firm's formal internal governance due to ownership concentration and control by small number of family owners and/or owner-managers (Chrisman, Chua, Breton-Miller, Miller, \& Steier, 2018), and also the heterogeneity among these firms regarding the adoption of various family governance structures (Arteaga \& Escribá-Esteve, 2020; Gersick \& Feliu, 2013; Suess, 2014).

Thus, a three-circle model of family business system is used to explain the interrelated governance structures. This model was developed at Harvard 
Assoc. Prof. Dr. Murad Mohammed Abdullah Al-Nashmi Dr. Mohammed Ahmed Ali Shujaa Aldeen $\dot{0}$

Business School in 1978, as shown in figure (1), and has been accepted worldwide as a central organizing framework used by families, academics and consultants to understand family business systems since then (Davis, 2019). The need to the three-circle model lies in the fact that such circles are constantly intertwined which results in poor communication and lack of family members' commitment and hence comes the significance of governance structure for each circle to prevent such problems (Gersick \& Feliu, 2013). Therefore, we stretch the knowledge of family business governance by distinguishing the governance structures related to the family circle and those related to the business system

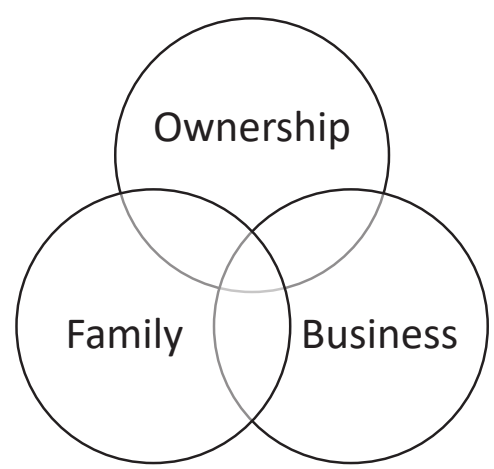

Figure 1. The three-circle model of family business

Source: (Davis, 2019).

\section{First: Governance in the Family Circle}

One common and simple form of family governance structures is the family meeting (Fahed-Sreih, 2009; Neubaver \& Lank, 1998). Family meeting is a wide-ranging tool that can be seen in various models (Koładkiewicz, 2014) used by families to discuss business matters, develop joint solutions, enhance the relation between the family and the firm, as well as initiating important debate on matters affiliating with the separation of ownership from management, succession plans, shares issues and the roles of the family council which can substantially vary from those of family meeting (Habbershon \& Astrachan, 1997; Saleem, Khalid, \& Nadeem, 2019; Suess, 2014). Family meetings may continue until the transition is made to a sibling partnership where pressure and demands for family assemblies or family forums increase. Both family meetings and family assemblies are considered informal family governance structures while assemblies are even more needed once the family reaches the cousin consortium to avoid potential 
conflicts triggered by larger shareholder groups, multiple branches, and active/non-active shareholders (Neubaver \& Lank, 1998; Sua're \& SantanaMartı'n, 2004).

As the family assembly reaches a critical number of members, family council can be developed to form a more established family governance structure (Neubaver \& Lank, 1998) which is considered to be the most frequent family governance mechanism in the literature (Suess, 2014). Family council may include multiple branches and/or generations who periodically come together to discuss issues arising from their family's involvement with a business (Berent-Braun \& Uhlaner, 2012; Gersick \& Feliu, 2013; Koeberle-Schmid, Kenyon-Rouvinez, \& Poza, 2014). Family council can influence and affect the performance of the family firm (Daspit, Chrisman, Sharma, Pearson, \& Mahto, 2018) and operate as a central governance tool that extends far beyond the purpose of governing the family (Ediriweera, Armstrong, \& Heenetigala, 2015; Gallo \& Kenyon-Rouvinez, 2005; Suess, 2014). The family council may also serve other functions relating to the building of family team works such as developing shared vision, discussing and clarifying members' roles as well as enhancing norms of behavior needed for future family owners and managers (Berent-Braun \& Uhlaner, 2012; Brenes, Madrigal, \& Requena, 2011) The family council can also partially substitute roles of other governance mechanisms such as shareholders' meeting and the board of directors, namely ownership and monitoring (Gnan, Montemerlo, \& Huse, 2013).

Family constitution is another family governance structure which is also referred to as a family protocol, family code of conduct, family statement, or family plan (Berent-Braun \& Uhlaner, 2012; Botero \& Vergara, 2015; Suess, 2014). Family constitution is a document including policies, philosophies, rules, and values written and communicated within the family and the business to better enhance communication, resolve conflict and also define the roles, compositions, and functions of family governance institutions and the company's own governance bodies, such as the shareholders' meeting, the board of directors and senior management (Astrachan \& Stider, 2005; Botero \& Vergara, 2015; Brenes et al., 2011; Gallo \& Kenyon-Rouvinez, 2005; Sarbah \& Xiao, 2015; Uhlaner, 2006).

Finally, family committees are specific task entity created by highly active families which can play a significant governance role as verifying compliance 
with family's values, appointing candidates for the position of the firm CEO or the board of directors, resolving, and managing conflicts on specific shareholders' issues (Ediriweera et al., 2015; Neubauer \& Lank, 1998; Saleem et al., 2019).

\section{Second: Family Business Governance System}

The nature of the family business requires not only focusing on family governance structures in the family circle (family meeting, family assembly, family council, family constitution, and family committees), but also addressing formal governance mechanism such as board of directors, CEOs as well as other structures pertaining to ownership such as shareholders meeting or family offices that can be developed by advanced family businesses. Therefore, owner-managers in family firms need to deal with the desires of these parties, namely the family, business, and ownership, while understanding how these three subsystems overlap (Tagiuri \& Davis, 1992).

The board of directors is a formal and core element of family business governance structure (Cadbury, 2000; Daspit et al., 2018; Heuvel, Gils, \& Voordeckers, 2006; Maseda, Iturralde, Aparicio, Boulkeroua, \& Cooper, 2019) where issues related to corporate governance usually fall upon the board of directors and factors affiliating with its selection, responsibilities, composition, size, age, and gender affect the board efficiency and impact the firm's top management functions (Briano-Turrent \& Poletti-Hughe, 2017; Ediriweera et al., 2015; Jaskiewicz \& Klein, 2007; Wilson, Wright, \& Scholes, 2013). While the primary function of the board is the provision of advice for the CEO and management as well as its control task (Bammens, Voordeckers, \& Gils, 2011), it also aligns the business strategy with the interests of its stockholders, acts as a communication link among shareholders and top management and accordingly mitigating agency problems, and ensures objective and fair treatment of all the family business stockholders (Maseda et al., 2019; Brenes at al., 2011 ). Furthermore, different forms of board can result from different phases of ownership which may include an advisory council formed by the controlling owner, a more decision-making kind of board in the second generation, where siblings generally are effective members in the board, and board with family owner representatives to gain some confidence of the board's functions in third generation family firms (Anderson \& Reeb, 2004; Brenes et al., 2011; Gallo \& Kenyon-Rouvinez , 2005). 
In addition to the board of directors, CEOs and top management are important governance structures in family businesses with key roles pertaining to the execution of strategy as well as the provision of relevant and reliable information to the board and stockholders (Brenes et al., 2011).

However, the heterogeneity of family businesses can also be seen in the duality of chair of the board and the CEO. For instance, while CEO duality issues impose a need to adopt governance practices to avoid the development of poor family politics, family entrenchment or conflicts of interest (Braun \& Sharma, 2007; Saleem et al., 2019), yet such duality can be important for the performance of the family firm (Gama \& Rodrigues, 2013; Saidat, Silva, \& Seaman, 2018) and can reduce some agency costs triggered by the separation of the titles, CEO and chairman position (Brickley, Coles, \& Jarrel, 1997) despite the fact that the relationship between duality and performance in family firms can be contingent on factors such as the presence and ownership of the family control while suggesting CEO duality to be better for non-family firms (Lam \& Lee, 2008).

\section{Family Business Governance and Organizational Innovation}

Prior studies show that relevant routines related to family firm governance structures such as family meetings, constitution, board of directors, and idiosyncratic values of family members involved in owning and managing the firm can collectively constitute unique competitive advantages that lead to innovation in the family firm (Bughin \& Colot, 2010; Campbell \& Heriot, 2002; Eddleston, Kellermanns, \& Sarathy, 2008; Habbershon \& Williams, 1999; Massis, Kotlar, Frattini, Chrisman, \& Nordqvist, 2016; Matzler, Veider, Hautz, \& Stadler, 2015; Minetti, Murro, \& Paiella, 2015; Sirmon \& Hitt, 2003).

The results of a meta-analysis of 108 main studies conducted in 42 different countries show that family firms are better and well-suited in turning innovation inputs into innovation outputs such as product and process innovation and that such firms develop needed resources more efficiently than their counterparts due to the substantial involvement of family members in these firms (Duran et al., 2016).

Such involvement of family members operates as mechanisms that produce better rate of conversion regarding innovation, indicating that family firms are more efficient in utilizing innovation input than their counterparts' nonfamily firms (Dibrell et al., 2018; Diéguez-Soto et al., 2018). Additionally, the combination of governance modes pertaining to family control and family 
management leads to higher innovation performance (Arteaga \& EscribáEsteve, 2020; Bughin \& Colot, 2010).

Furthermore, family firms perform better when family ownership is concentrated and where active family governance exists, leading family members to work together more as stewards in enhancing and facilitating the firms' activities, and optimizing its outputs (Ciftci, Tatoglu, Wood, Demirbag, \& Zaim, 2019; Lee \& Chu, 2017; Miller et al., 2017).

Our study refers to agency theory as a fundamental theory that has been central to literature concerning family firms (Hillier, Martınez, Patel, Pindado, \& Requejo, 2018) which supports the formal governance structures and some informal family governance structures such as the family constitution. We also employ the stewardship theory which promotes innovation

(Zahra, Hayton, Neubaum, Dibrell, \& Craig, 2008) in the sense that stewardship behaviors act as an effective governance mechanism for family businesses by linking stewardship behaviors to innovativeness (Criag, Dibrell, \& Neubaum, 2011).

While the relation between the family firm governance and the firm innovation has been a considerable research topic as stated in the literature, it is still not easy to address such issue due to the heterogeneity of family firms in matters related to family matters, family culture and values, distinctive governance structures and generational involvement. Innovativeness is another discrepancy found among studies about family firms. For instance, family firms are found to be successful innovators and that the business family, owning family members and/or managing members, have a considerable and a major influence on the innovation outputs and longevity of these family firms (Ahmad, Omar, \& Quoquab, 2021; Craig, Dibrell, \& Davis, 2008; Dibrell, Gamble, Sherlock, \& Swab, 2018; Diéguez-Soto, Garrido-Moreno, \& Manzaneque, 2018; Duran, Kammerlander, Essen, \& Zellweger, 2016; Frank, Kessler, Bachner, Fuetsch, \& Suess-Reyes, 2019).

Nevertheless, as the level of family involvement through the family business governance can have a positive impact on the firm's performance (Dibrell et al., 2018), it's still not clear why so many other family firms prefer different levels of family members' involvement in both control and management. According to Miller et al. (2017), there is a need to investigate the heterogeneity of family firm governance in relation to its performance and emphasize the need to explore the effect of family models of governance within different countries. 
There is still a need to examine how family management in general can affect the performance yielded from process innovation outcomes (Diéguez-Soto et al., 2018). This goes well with suggestions by other researchers who believe that the relationship between governance and innovation in family firms has been under-researched and requires further study to better clarify how family business governance triggers innovation in family firms (Kellermanns, Eddleston, Barnett, \& Pearson, 2008; Li \& Daspit, 2016; Massis et al., 2013; Memili, Singal, \& Barrédy, 2016; Suess, 2014).

Furthermore, the current situation in Yemen is increasingly deteriorating due to the ongoing brutal war. According to a survey finding report by the World Bank Group (WBG) in October 2018 on the impact of the current war in Yemen on its economy as it states that more than 25\% of businesses in Yemen completely shut down, over $51 \%$ of firms currently working have decreased in size and scaled down their operations as well as a reduction of Yemeni sea ports capacity by an estimated 25 to 50\% (IBRD, IFC, \& MIGA, 2019; Sofan, 2018). However, and in spite of this aggression, business organizations in Yemen, including family firms have managed to stand against such challenges through the adoption of innovation as a means to better adapt to external changes and threat, since innovation is perceived to be a practical method to react to unstable surroundings and external changes (Archibbugi \& Daniele, 2010; Budros, 2000), and since organizational innovation is specifically needed and crucial for the firm survival (Demircioglu, 2018; Pauget \& Wald, 2018).

Based on the above discussions, this study examined 219 family firms in Yemen to answer the following questions; what is the impact of family business governance on the organizational innovation? what is the impact of formal governance structures (board of directors, CEOs and top management) and informal governance structures (family constitution, family council, annual general meeting) on product and process innovation in family firms? The findings of this study have several contributions to theory, methodology, and also practice.

This study contributes to the body of the literature by responding to the need for empirical research addressing the heterogeneity and inconsistency of findings of prior studies in the literature which calls for further investigation (Miller, Breton-Miller, Amore, Minichilli, \& Corbetta, 2017). For instance, Massis, Frattini, and Lichtenthaler (2013) argue that the prior researches in 
regard to the impact of family business governance on innovation outputs collectively provide inconsistent results. Most importantly, prior research on family business governance and organizational innovation has never been investigated in under developing countries, like Yemen, during extremely unstable political and economic periods.

Therefore, based on the arguments stated in the literature and in line with the research questions as well as the objectives of the study mentioned earlier, the following hypotheses were developed:

H1. Family business governance has a positive impact on organizational innovation.

The variable 'family business governance' in this study includes dimensions that encapsulate all the three circles of family business systems as developed by Harvard Business School (Davis, 2019) in which family, business, and ownership are intertwining with each other which suggests the need to examine the proposed hypothesis. Hence, the three dimensions related to family business governance included: (family constitution and family council) that represent the family circle, (board of directors, CEO and management) that represent the business circle, and (annual general meeting) which represents the ownership circle. In that regard, dimensions of the variable "family business governance" are all supported by the agency theory.

More importantly, agency theory serves the purpose of the current study and is referred to when investigating the mechanisms of family governance regarding the interactions between and among family firms' principals and agents which eventually affect the family firm's activities such as product innovation (Massis et al., 2016). Based on the above discussions, the following sub-hypotheses were developed:

H1a. Family constitution has a positive impact on organizational innovation.

Craig and Moores (2006) assume family firms to have higher degree of innovation as triggered by its internal communication practices which, according to Gersick and Feliu (2014) are relevant output of the family governance structure serving to maintain trust and align the goals of the family and the business. The relevance of family governance structures is seen as they link all family members involved, develop a sense of stewardship and pride, control and monitor the development of family leaders and the progress of family constitution and council and promote family values 
(Gallo \& Kenyon-Rouvinez , 2005; Koładkiewicz, 2014). Therefore, the conceptual framework refers to stewardship theory that supports family governance structuresand therefore, the following hypothesis was developed:

H1b. Family council has a positive impact on organizational innovation.

Other formal family business governance structures are board of directors, CEO and top management, as well as the annual general meeting held by the owners (Cadbury, 2000; Daspit et al., 2018; Gallo \& Kenyon-Rouvinez, 2005; Heuvel et al., 2006; Maseda et al., 2019). Based on this and in line with the research study questions, the following hypotheses were developed:

H1c. Board of directors has a positive impact on organizational innovation.

H1d. CEO and management have a positive impact on organizational innovation.

H1e. Annual general meeting has a positive impact on organizational innovation.

\section{Control variables}

This study identified two control variables in accordance with a future suggestion by Memili et al. (2016), indicating the need to explore other contingencies besides family governance forms, such as the size of the family firm and the generation in charge which may influence the family firm outcomes such as the product innovation and process innovation in this study. The first control variable was the size of the family firm which was measured by the number of the staff that the family firm has. Hence, family firms with 10 to 50 staff were categorized as middle-sized firms, while family firms with more than 50 were categorized as large family firms. The second control variable was the generation in charge which was measured as either the first generation, second, third, fourth generation or even farther as some family firms may carry on their family business for more than four generations. Therefore, the following hypothesis was developed to examine any differences in the organizational innovation in regard to the control variables "size" of the family firm and "generation in charge".

H2. There is a difference in organizational innovation among family firms due to the size of the firm and the generation in charge. 


\section{Methodology}

\subsection{Research design}

This study referred to relevant literature regarding the design of methodology in the sense that recent studies investigating innovation and governance in family firms used PLS-SEM (Calabrò, Campopiano, Basco, \& Pukall, 2017; Craig, Dibrell, \& Garrett, 2014; Leal-Rodríguez, Albort-Morant, \& MarteloLandroguez, 2016; Lee \& Chu, 2017; Pittino, Martínez, Chirico, \& Galván, 2018) since PLS-SEM enables the analysis of all paths, both measurement and structural in one analysis, and examines multiple indicators in regard to each construct while coping with relatively small sample size (Ramli, Latan, \& Nartea, 2018) such as the sample this study has.

In that regard, most significant measurement model metrics used for PLSSEM are convergent validity, reliability, and discriminant validity. Follows are the significant evaluation metrics related to the structural model such as the coefficient of determination $R^{2}, f^{2}$ (effect size), $Q^{2}$ (predictive relevance), as well as the size and the statistical significance of the structural path coefficients (Hair, Hult, Ringle, \& Sarstedt, 2017). The study then pursued systematic steps to evaluate and test the research model and hypotheses summed as follows:

\section{Stage 1: Evaluation of the measurement model}

- Internal Consistency

- Convergent Validity

- Discriminant Validity weights

- Nomological Validity

- Collinearity among indicators

- Significance and relevance of Outer weights

Stage 2: Analyzing research model and validating first \& secondorder constructs

\section{Stage 3: Evaluation of structural model}

- Significance and the relevance of the structural model path coefficients

- Coefficient of determination $R^{2}$

- $f 2$ effect sizes

- The predictive relevance $Q 2$ and $q 2$ effect sizes

- Assessment of model's predictive power (PLSpredict)

\section{Stage 4: Testing the study hypotheses}




\subsection{Study population}

Identifying the study sample is of paramount importance to ensure the accuracy and validity of the study and accordingly a throughout identification of the study population was a crucial factor in that regard. The study, therefore, relied on official record for firms registered by the Chamber of Commerce and Industry (CCI) for the last three years (2016- 2017- 2018) to identify the study population which amounts for 2045 firms, most of which are headquartered in the capital Sana'a. Since $90 \%$ of the licensed and operating companies in Yemen are small and medium-sized family enterprises (YBC, 2016a), the study population identified was accordingly 1840 family firms.

Nevertheless, and to serve the purpose of this study, certain factors were considered to come up with a more accurate sample for the study. These factors included the size of the family firms regarding the number of employees. Thus, a minimum number of 10 employees and up to 49 was set as medium-sized firms while large firms have 50 and more employees. Besides, as for the date of establishment of targeted firms, a duration of 10 years is set as minimum duration which, along with its size, was an indicator of the maturity of the family firm to formally assume governance structures. The last factor is the generation that owns and controls the family firm where targeted firms must be at least owned and/or controlled by the founding owner (founder) and sibling partnership or by sibling partnership, if not by the third or the fourth generation.

Furthermore, while the study used official record for family firms registered by the Chamber of Commerce and Industry $(\mathrm{CCl})$ as a secondary source of data to assess the study population, a lot of these firms were small family firms and therefore were excluded from the study for reasons pertaining to their immature governance structures that would not likely serve the purpose of the study. Besides, the number of family firms still operating during the data collection period (1 $16^{\text {th }}$ Sept. 2019 till $5^{\text {th }}$ Feb, 2020) was less than the registered ones, as some of these firms either seized their businesses, moved to Hadhramaut, a region in southern Arabia, in east-central Yemen or even invested outside Yemen in countries mostly located in Africa (north and north east Africa). This is also indicated in a survey findings report by the World Bank Group (WBG) in October 2018 on the impact of the current war in Yemen on its economy, stating that more than 25\% of businesses in Yemen 
completely shut down, over $51 \%$ of firms currently working have decreased in size and scaled down their operations to cut-down on costs, and a reduction of Yemeni sea ports capacity by an estimated 25 to 50\% (IBRD, IFC, \& MIGA, 2019; Sofan, 2018).

In light of all factors stated above, the population fitting the purpose of the study was 800 family firms where most of them are headquartered in the capital city Sana'a while holding their subsidiaries in other governorates around Yemen.

\subsection{Sample selection}

Given the study population, an appropriate study sample of 260 family firms was identified. The study sample was determined using Robert Manson's formula as follows:

$$
n=\frac{M}{\left[\left(S^{2} \times(M-1)\right) \div p q\right]+1}
$$

$\mathrm{n}$ : required sample size

M: population

S: The division of the standard score corresponding to the level of significance is 0.95 , It means 1.96 divided by the error rate 0.05

P: Availability ratio of the property is 0.50

$\mathrm{q}$ : The remaining property is 0.50

$$
\begin{aligned}
& n=\frac{800}{\left[\left(0.02551^{2} \times(800-1)\right) \div 0.25\right]+1} \\
& n=\frac{800}{[(0.000651 \times(799)) \div 0.25]+1}=259.751
\end{aligned}
$$

$n=260$

Hence, the targeted sample is 260 family-owned firms. The study used a simple random sample in identifying target family firms and then used a purposive sample to identify individual owners, members of the board of directors and CEOs or senior managers inside these firms. To guarantee the retrieving of sufficient number of applicable questionnaires, a total of 350 paper questionnaires were distributed. The total questionnaires retrieved after 
excluding incomplete questionnaires were 219 (193 paper questionnaires and 26 web-based questionnaires). Both retrieved questionnaire forms made up $73 \%$ of the overall distributed questionnaires and $84 \%$ of the targeted sample (260 family firms).

\subsection{Unit of analysis}

The importance of accurate define of unit of analysis lies in its crucial role that can affect both the applicability of the study analysis methods and the generalizability of the findings (Kumar, 2018). Since the present study examined the impact of family business governance on the organizational innovation, and that the variables of the study could only be measured at the level of organizations, the unit of analysis was at the organizational level and data was collected from family members who were owners, members of the board of directors, CEOs or senior managers. Table (1) shows the number of family members in different generations of family firms targeted in this study.

Table 1. Generation in Charge

\begin{tabular}{ccc}
\hline & Frequency & Percent \\
\hline $1^{\text {st }}$ & 33 & 15.1 \\
$2^{\text {nd }}$ & 133 & 60.7 \\
$3^{\text {rd }}$ & 42 & 19.2 \\
$4^{\text {th }}$ & 3 & 1.4 \\
Others & 8 & 3.7 \\
Total & 219 & 100.0 \\
\hline
\end{tabular}

\subsection{Data collection methods}

Data was collected through questionnaires sent to respective respondents from selected sample of family-owned firms. The questionnaire used a fiveitem Likert-scale ranging from 'strongly agree' to 'strongly disagree'. To guarantee the functionality of such vivid instrument, the questionnaire was first drafted in English as the main study instrument used to collect data and was translated into Arabic language. This was important since backtranslation

helps ensure the meaning of item statements in the translated questionnaire will not change and the language is accurate (Kreiser, Marino, \& Weaver, 2002). The questionnaire was then validated by a group of academic experts, professional business people operating in their family firms, experts in YBC and professional statisticians. The questionnaire was then distributed in two 
forms as follows:

- Paper questionnaire form: Dedicated team members helped distribute the questionnaires to targeted members in family-owned firms.

- Electronic questionnaire form: A special Web-based questionnaire was mainly designed to reach family members as owners, CEOs, or senior managers in relatively large family firms who were not available in their family firms the time paper questionnaires were distributed, or due to difficulties reaching them in person. The URL link used was the one stated down as: (https://forms.gle/jav4RoKfMBENheQx9).

\subsection{Study instrument and scale}

The study instrument was used to collect data required for the study including the family business governance FBG, and organizational innovation OIN. In addition to study variables used to hypothesize the relationships, a number of other variables important in understanding the organizational innovation in family firms were also considered in this study such as size of family firms and the generation in charge. In that regard, a number of studies were used to develop the study instrument and scale as follows:

1. Organizational innovation: This dimension was comprised of two variables measuring the organizational innovation in terms of its types (product and process innovation) (Demircioglu, 2018) which were the most common types of dimensions used to conceptualize the firm innovation in the literature (Knowles, Hansen, \& Dibrell, 2008). The present study, therefore, employed a 14-item scale to measure organizational innovation as adopted by Chen, Zheng, Yang, and Bai (2016), Dibrell et al. (2018) and Knowles et al. (2008).

2. Family business governance: A 20-item scale comprised of 5 dimensions was used to measure family business governance based on the three-circle model of family business system developed at Harvard Business School in 1978 by Renato Tagiuri and John Davis which, since then, has been accepted worldwide as a central organizing framework used to investigate governance mechanisms in family firms (Davis, 2019). Another reason why the present study used the three-circle model is the fact that such circles (ownership, business, family) are constantly intertwined which results in poor communication and lack of family members commitment which explains the significance of governance structure for each circle to prevent such problems (Gersick \& Feliu, 2013). In that regard, the scale used to measure the family business governance utilized items pertaining to the three-circle model used by Klein (2000).

\section{Empirical results}

The conduction of bootstrapping yields the results of path coefficient, t-values and significance level. Figure (2) reveals clearly the proposed positive effect 
in regard to family business governance and organizational innovation which, as table (1) shows that family business governance has a significant impact on organizational innovation (Beta $=0.618 ; \mathrm{T}=13.698 ; \mathrm{P}<0.05$ ), and therefore, the first main hypothesis (Family business governance has a positive in

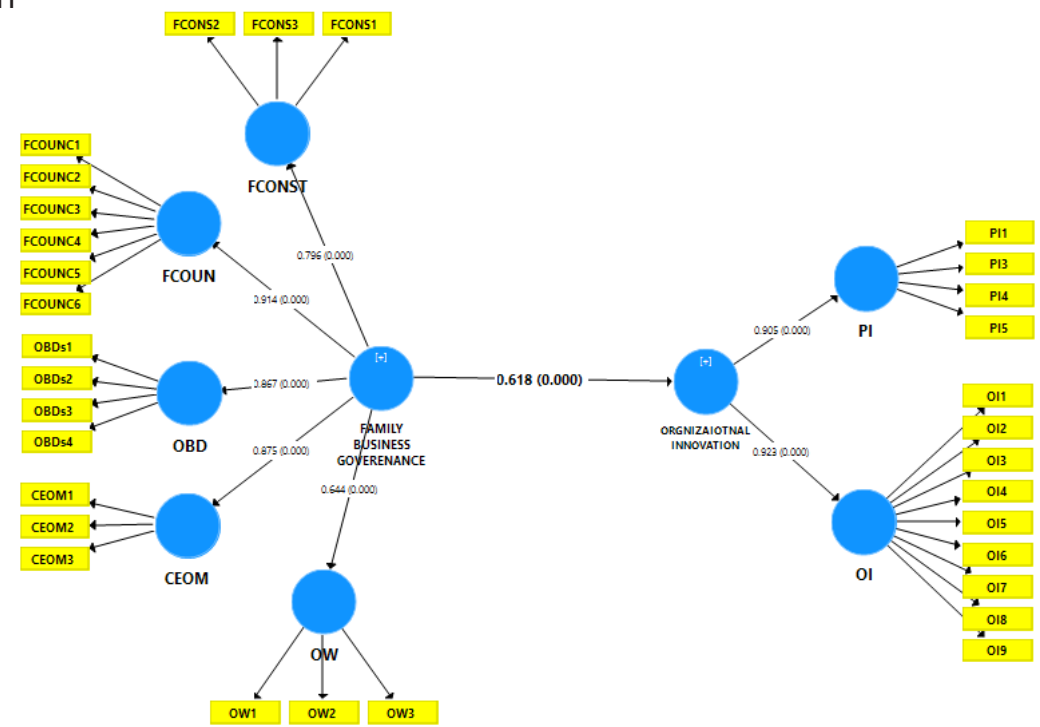

Figure 2. Path Coefficients "Main Hypothesis"

Table 2. Result of Main Hypothesis Testing

\begin{tabular}{cccccc}
\hline Path & Beta & SD & T & P Values & Supported \\
\hline $\begin{array}{c}\text { Family Business Governance } \\
\rightarrow \text { Organizational Innovation }\end{array}$ & 0.618 & 0.045 & 13.698 & 0.000 & Yes \\
\hline
\end{tabular}

The results reveal that the family business governance has a significant impact on the organizational innovation in these firms. The path coefficients and bootstrapping in SmartPLS were examined as reported in (Table 2) showing that family business governance had a significant impact on organizational innovation (Beta $=0.618 ; \mathrm{T}=13.698 ; \mathrm{P}<0.05$ ) and accordingly supporting the major hypothesis $\mathrm{H} 1$. The results indicate that the application of family business governance practices promotes better results at the organizational level of these family firms seen as product innovation and process innovation. This is because family members involved in both owning and managing the family business are directly linked to the formulation of the firm's vision and mission as well as the firm's strategy while adhering to vivid governance 
practices at the level of the family (informal family governance) and at the level of the business (formal family business governance). The results also show that only two sub-hypotheses regarding the impact of family business governance on the organizational innovation are found to be insignificant $\mathrm{Hla}$, (Family constitution has a positive impact on organizational innovation) where Beta=-0.008; $\mathrm{T}=0.094 ; \mathrm{P}>0.05$ and $\mathrm{H} 1 \mathrm{c}$ (Board of directors has a positive impact on organizational innovation) Beta $=-0.013 ; \mathrm{T}=0.138$, $\mathrm{P}>0.05$. The other three sub-hypotheses, $\mathrm{H} 1 \mathrm{~b}$, (Family council has a positive impact on organizational innovation), $\mathrm{Hld}$, (CEO and management have a positive impact on organizational innovation), and $\mathrm{Hle}$ (Annual general meeting has a positive impact on organizational innovation) are found to be significant.

The path coefficients and bootstrapping results in SmartPLS as reported in figure 3 and table 3 reveal positive impact of family council, CEO and management, and the annual general meeting on organizational innovation with (Beta=0.204; $\mathrm{T}=2.127 ; \mathrm{P}<0.05)$, (Beta=0.253; $\mathrm{T}=2.531 ; \mathrm{P}<0.05)$ and $($ Botr $=\cap 2 २ \% \cdot \mathrm{T}=5 \Lambda<1 \cdot \mathrm{P}<\cap \cap 5)$ rocnortivaly

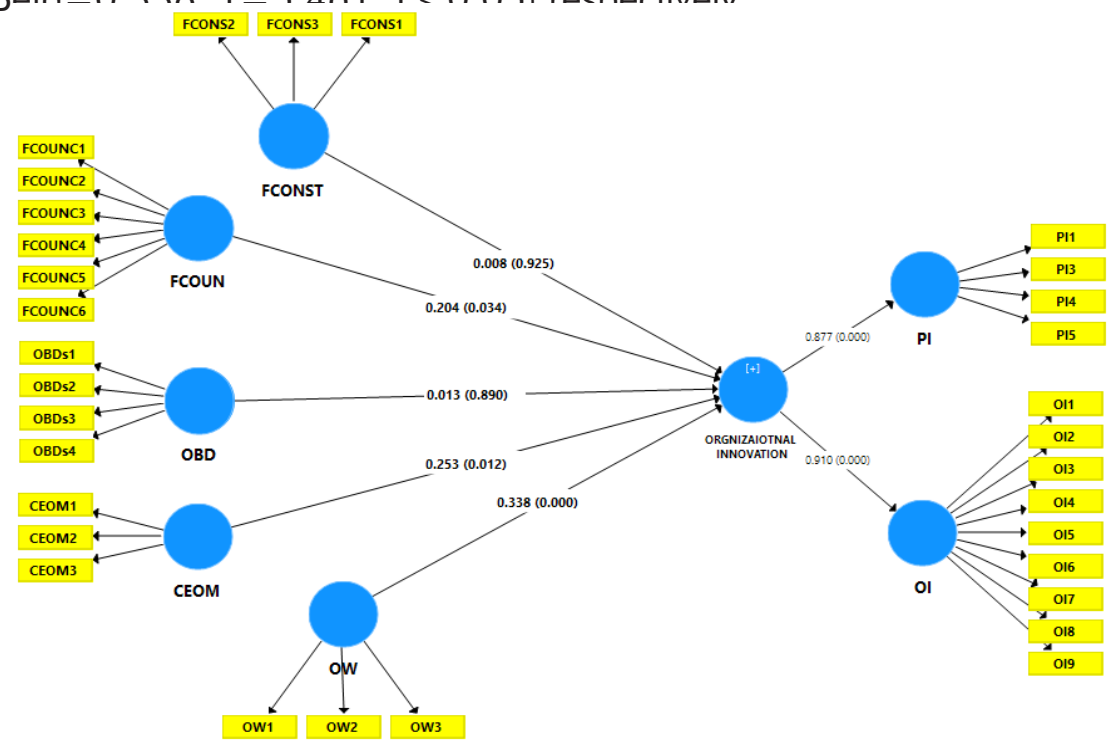

Figure 3. Path Coefficients "Sub-Hypotheses" 
Table 3. Result of Sub-Hypotheses Testing

\begin{tabular}{ccccccc}
\hline Hypothesis & Paths & BETA & (SD) & t values & p values & Supported \\
\hline Hla & FCONS $\rightarrow$ OIN & 0.008 & 0.090 & 0.094 & 0.925 & No \\
H1b & FCOUN $\rightarrow$ & 0.204 & 0.096 & 2.127 & 0.034 & Yes \\
& OIN & & & & & \\
H1c & BODs $\rightarrow$ OIN & 0.013 & 0.096 & 0.138 & 0.890 & No \\
H1d & CEOandM $\rightarrow$ & 0.253 & 0.100 & 2.531 & 0.012 & Yes \\
& OIN & & & & & Yes \\
\hline
\end{tabular}

Regarding the second main hypothesis, namely (There is a difference in organizational innovation among family firms due to the size of the firm and the generation in charge), theresults reveal significant differences in organizational innovation that can be attributed to the size of the firm $(t=2.862, p<0.05)$ in favor of those family firms that have more than 50 staff over those that have 10-50 staff. On the other hand, there is no significant difference in the organizational innovation that can be attributed to the generation in charge of the family firm ( $f: 5,213=1.418 ; p>0.05)$.

\section{Discussion}

The findings show that family business governance has a significant positive effect on organizational innovation in family firms operating in Yemen. The findings are supported by prior studies (Dieleman, 2019; Frank et al., 2019; Gerulaitiene, Pundziene, \& Vaiciukynaite, 2020; Matzler et al., 2015; Memili et al., 2016). On the other hand, the results concerning the non-significant impact of family constitution on organizational innovation in family firms can be argued to exist due to the very few numbers of family firms in Yemen that have developed family constitutions. According to YBC (2016b), only $10 \%$ of the Yemeni family firms have developed family constitutions which explains the above stated results. YBC also recommends to encourage Yemeni family firms to develop their own family constitutions to ensure the sustainability and growth of their family businesses. Regarding the board of directors, we find that most managers in family firms are family members who are mostly in the second generation (60.7\%) as stated in table (1). Those managers are closely tied and still dominated by family members in the first generation and accordingly rely more on family meetings and/or family council in discussing the family business matters, which, accordingly, supports the agency theory. This may explain why boards of directors have no impact on organizational innovation in the sense that boards of directors in Yemeni family firms have 
not by far shifted from a family-relationship kind of organization to a more business-relationship one, which, according to Cadbury (2000), is a necessity to establish a board of directors. We find that the reliance of family councils, or family meetings, is very fundamental for Yemeni family firms in discussing urgent and important decisions and strategies by selected family members who represent the ownership circle in the family business. In some cases, such discussions are conducted through informal family gatherings such as Qat sessions as known in Yemen.

\section{Conclusion}

This study has examined the organizational innovation in family firms with respect to the effect of family business governance on these firms' innovativeness. The results showed that family business governance has a significant positive impact on organizational innovation in family firms operating in Yemen. The results reveal the importance of family business governance structures with respect to the organizational innovation in family firms.

The majority of managers are members in the second generation who operate under the supervision of family members in the first generation. Hence, those managers refer to matters discussed in family meetings and family councils which supports the agency theory.

The reliance of special family council, or family meetings, was very fundamental in discussing urgent and important decisions and strategies by selected family members who represent the ownership circle in the family business. Such discussions are even conducted through informal family gatherings such as Qat sessions as known in Yemen.

This study also provides several contributions to family business research and also to innovation research. Essentially, it contributes by adding to the discussion concerning the effect of family business governance on innovation in family firms. This is particularly important given the inconsistency and the inconclusive of findings in the literature (Asensio-López, Cabeza-García, \& González-Álvarez, 2019) which, according to Li and Daspit (2016), is quite expected due to the heterogeneity of family firms in different matters as compared to their counterparts, non-family firms, which also leads to the adoption of different governance mechanisms (Arteaga \& Escribá-Esteve, 2020). 
The study recommends owners of family firms to prepare their family constitutions to ensure their continuity and growth across generations, foster motivating innovativeness through well-developed formal and informal family governance structures, practically exhibit shared values that promote and convey the sense of commitment to entrepreneurship and innovation, and embrace non-family managers and members in the board of directors to stimulate more innovative strategies needed to gain better organizational innovation in their firms.

\section{Limitations and future research directions}

This study has a number of limitations that should be taken into account when interpreting the results. However, some of the limitations as stated herein help provide opportunities for future directions relevant to main topic of this study. First, given the nature of ownership in Yemeni family firms, this study assumes a complete ownership of the family firms by family members only. In that regard, the study did not address the potential influence of external partners on the organizational innovation in family firms in Yemen. Such openness and its impact on organizational innovation represent an interesting path for future studies, especially in Yemen and the gulf countries. Second, this study investigated the impact of family business governance on organizational innovation while only considering the second or the third generation in charge as a control variable. In other words, the study did not consider the extent to which family business governance, as mechanism, can change due to the transition of control from one generation to another, and hence, how such altered governance structure impact organizational innovation when compared with the former generation mechanisms. This provides some interesting insights into the role of generation succession in Yemeni family firms and its impact on the organizational innovation in these firms. Third, the study emphasized the types of the organizational innovation as an approach to address the problem and accordingly employed product innovation and process innovation as the two aspects of the organizational innovation. Hence, future research is still needed to measure organizational innovation from different approaches such as sources of organizational innovation (e.g., top-down sources, bottom-up sources, external sources) and in line with influence of the governance mechanisms used by these family firms. 
Assoc. Prof. Dr. Murad Mohammed Abdullah Al-Nashmi Dr. Mohammed Ahmed Ali Shujaa Aldeen

\section{Authors' contribution}

MMAA and MAASA developed the introduction, literature review, the problem statement, and the research objectives, and designed the research methodology. MAASA collected and analyzed the data. Both authors contributed to the interpretation of results. MAASA contributed to the conclusions and recommendations and revised the manuscript. Both authors read and approved the final manuscript.

\section{References}

Ahmad, S., Omar, R., \& Quoquab, F. (2021). Family firms' sustainable longevity: The role of family involvement in business and innovation capability. Journal of Family Business Management, 11(1), 86-106. doi:10.1108/JFBM-122019-0081

Alves, M. F., Galina, S. V., \& Dobelin, S. (2018). Literature on organizational innovation: past and future. Innovation \& Management Review, 15(1), 2-19.

Anderson, R. C., \& Reeb, D. M. (2004). Board composition: Balancing family influence in S\&P 500 firms. Administrative Science Quarterly, 49(2), 209-237.

Archibbugi, A., \& Daniele, F. (2010). Innovation in times of crisis: National Systems of Innovation, structure, and demand. Research Policy, 40(2), 1-14. doi:10.1016/j.respol.2010.09.001

Armbrustera, H., Bikfalvi, A., Kinkel, S., \& Lay, G. (2008). Organizational innovation: The challenge of measuring non-technical innovation in largescale surveys. Technovation, 28(10), 644-657.

Arteaga, R., \& Escribá-Esteve, A. (2020). Heterogeneity in family firms: contextualising the adoption of family governance mechanisms. Journal of Family Business Management, $17(2), 200-222$. doi:10.1108/JFBM-102019-0068

Asensio-López, D., Cabeza-García, L., \& González-Álvarez, N. (2019). Corporate governance and innovation: A theoretical review. European Journal of Management and Business Economics, 28(3), 266-284.

Astrachan, J. H., \& Stider, A. K. (2005). Family. In D. Kenyon-Rouvinez, \& J. L. Ward (Eds.), Family business: Key issues (pp. 31-43). London: Palgrave Macmillan.

Bammens, Y., Gils, A. \& Voordeckers, W. (2010, August). The role of family involvement in fostering an innovation-supportive stewardship culture. In academy of management proceedings (vol. 2010, no. 1, pp. 1-6). Briarcliff Manor, NY: Academy of Management. 
Bammens, Y., Voordeckers, W., \& Gils, A. (2011). Boards of directors in family businesses: A literature review and research agenda. International Journal of Management Reviews, 13(2), 134-152.

Berent-Braun, M. M., \& Uhlaner, L. M. (2012). Family governance practices and teambuilding: paradox of the enterprising family. Small Business Economy, $38,103-119$.

Botero, I. C., \& Vergara, M. P. (2015). Family protocols as governance tools understanding why and how family protocols are important in family firms. Journal of Family Business Management, 5(2), 218-237.

Braun, M., \& Sharma, A. (2007). Should the CEO also be chair of the board? An empirical examination of family-controlled public firms. Family Business Review, 20(2), 111-126.

Brenes, E. R., Madrigal, K., \& Requena, B. (2011). Corporate governance and family business performance. Journal of Business Research, 64(3), 280-285.

Briano-Turrent, G. d., \& Poletti-Hughe, J. (2017). Corporate governance compliance of family and non-family listed firms in emerging markets: Evidence from Latin America. Journal of Family Business Strategy, 8(4), 237 247.

Brickley, J. A., Coles, J. L., \& Jarrell, G. (1997). Leadership structure: Separating the CEO and chairman of the board. Journal of corporate Finance, 3(3), 189-220.

Budros, A. (2000). Organizational types and organizational innovation: downsizing among industrial, financial, and utility firms. Sociological Forum, 15(2), 273-306.

Bughin, C., \& Colot, O. (2010). Does family governance encourage innovation? Journal of Business and Economics, 2(2), 199-218.

Cadbury, G. A. (2000). Family firms and their governance: Creating tomorrow's company from today's. UK: Egon Zehnder International.

Calabrò, A., Campopiano, G., Basco, R., \& Pukall, T. (2017). Governance structure and internationalization of family-controlled firms: The mediating role of international entrepreneurial orientation. European Management Journal, 35(2), 238-248.

Campbell, N. D., \& Heriot, K. C. (2002). Which family-controlled business remain-family controlled? A resource based approach. In $16^{\text {th }}$ Annual USASBE National Conference Proceedings, 17-20 January, Pat Dickson. Reno, Nevada.

Chen, L., Zheng, W., Yang, B., \& Bai, S. (2016). Transformational leadership, social capital and organizational innovation. Leadership \& Organization Development Journal, 37(7), 843-859. 
Assoc. Prof. Dr. Murad Mohammed Abdullah Al-Nashmi Dr. Mohammed Ahmed Ali Shujaa Aldeen

Chrisman, J. J., Chua, J. H., Breton-Miller, I. L., Miller, D., \& Steier, L. P. (2018). Governance mechanisms and family firms. Entrepreneurship Theory and Practice, 42(2), 171-186.

Ciftci, I., Tatoglu, E., Wood, G., Demirbag, M., \& Zaim, S. (2019). Corporate governance and firm performance in emerging markets: Evidence from Turkey. International Business Review, 28(1), 90-103.

Craig, J. B., \& Moores, K. (2006). A 10-year longitudinal investigation of strategy, systems, and environment on innovation in family firms. Family Business Review, 19(1), 1-10.

Craig, J. B., Dibrell, C., \& Davis, P. S. (2008). Leveraging family-based brand identity to enhance firm competitiveness and performance in family businesses. Journal of Small Business Management, 46(3), 351-371.

Craig, J. B., Dibrell, C., \& Garrett, R. (2014). Examining relationships among family influence, family culture, flexible planning systems, innovativeness and firm performance. Journal of Family Business Strategy, 5(3), 229-238.

Criag, J. B., Dibrell, C., \& Neubaum, D. O. (2011). Stewardship Behaviour as governance in family businesses. In J. Farrar, \& S. Watson (Eds.), Contemporary issues in corporate governance (pp. 277-296). Christchurch: The Centre for Commercial \& Corporate Law Inc.

Damanpour, F. (1991). Organizational innovation: A meta-analysis of effects of determinants and moderators. Academy of Management Journal, 34(2), 555-590.

Daspit, J. J., Chrisman, J. J., Sharma, P., Pearson, A. W., \& Mahto, R. V. (2018). Governance as a source of family firm heterogeneity. Journal of Business Research, 84, 293-300.

Davis, J. A. (2019, September/October). Family business; How three circles changed the way we understand family business. Retrieved from family business magazine: https://bit.ly/32vcfOR

Demircioglu, M. A. (2018). Organizational Innovation. In A. Farazmand (Ed.), Global encyclopedia of public administration, public policy, and governance (pp. 4356-4360). Florida: Springer International Publishing AG.

Dibrell, C., Gamble, J., Sherlock, C., \& Swab, G. (2018). Family governance and firm innovativeness: The moderating roles of family pride and founding generation involvement. Paper presented at the $38^{\text {th }}$ Conference of Frontiers of Entrepreneurship Research (FER) and Babson College Entrepreneurship Research (BCER), Arthur M. Blank Center for Entrepreneurship, Babson College, Wellesley, Massachusetts. 
Diéguez-Soto, J., Garrido-Moreno, A., \& Manzaneque, M. (2018). Unravelling the link between process innovation inputs and outputs: The moderating role of family management. Journal of Family Business Strategy, 9(2), 114-127.

Dieleman, M. (2019). Reaping what you sow: The family firm innovation trajectory. Journal of Family Business Strategy, 10(4), 100248.

Duran, P., Kammerlander, N., Essen, M. v., \& Zellweger, T. (2016). Doing more with less: innovation input and output in family firms. Academy of Management Journal, 59(4), 1224-1264.

Eddleston, K. A., Kellermanns, F. W., \& Sarathy, R. (2008). Resource configuration in family firms: Linking resources, strategic planning and technological opportunities to performance. Journal of Management Studies, 45(1), 26-45.

Ediriweera, A., Armstrong, A., \& Heenetigala, K. (2015). Governance in family business: A literature review. Journal of Law and Governance, 10(2), 36-46.

Fahed-Sreih, J. (2009). An exploratory study on a new corporate governance mechanism Evidence from small family firms. Management Research News, 32(1), 50-61.

Frank, H., Kessler, A., Bachner, C., Fuetsch, E., \& Suess-Reyes, J. (2019). Principles for innovation management in family firms: An analysis of longterm successful good practices with a practitioner validation of the principles. Journal of Family Business, 9(3), 319-348.

Fu, Y., Liu, R., Yang, J., Jiao, H., \& Jin, Y. (2020). "Lean in": the moderating effect of female ownership on the relationship between human capital and organizational innovation. Journal of Intellectual Capital, 22(4), 792-814. doi:10.1108/JIC-10-2019-0236

Gallo, M. A., \& Kenyon-Rouvinez, D. (2005). The Importance of Family and Business Governance. In D. Kenyon-Rouvinez, \& J. L. Ward (Eds.), Family business key issues (pp. 45-57). New York: Palgrave Macmillan.

Gama, A. P., \& Rodrigues, C. (2013). The governance-performance relations in publicly listed family controlled firms: An empirical analysis. The International Journal of Business In Society, 13(4), 439-456.

Gersick, K. E., \& Feliu, N. (2013). Governing the Family Enterprise. In L. Melin, M. Nordqvist, \& P. Sharma (Eds.), The SAGE handbook of family business (pp. 197-218). London: SAGE Publication Ltd.

Gerulaitiene, N., Pundziene, A., \& Vaiciukynaite, E. (2020). The hidden role of owners> spouses in family firm innovativeness: A dynamic managerial capabilities perspective. Baltic Journal of Management, 15(5), 707-726. doi:10.1108/BJM-01-2020-0021

Global Data Points. (2017). Global Data Points. Retrieved March 3, 2019, from Family Firm Institute: https://my.ffi.org/page/globaldatapoints 
Assoc. Prof. Dr. Murad Mohammed Abdullah Al-Nashmi Dr. Mohammed Ahmed Ali Shujaa Aldeen

Gnan, L., Montemerlo, D., \& Huse, M. (2013). Governance systems in family SMEs: The substitution effects between family councils and corporate governance mechanisms. Journal of Small Business Management, 53(2), 355-381.

Habbershon, T. G., \& Astrachan, J. H. (1997). Research note perceptions are reality: How family meetings lead to collective action. Family Business Review, 10(1), 37-52.

Habbershon, T. G., \& Williams, M. L. (1999). A resource-based framework for assessing the strategic advantages of family firms. Family Business Review, 12(1), 1-25.

Hair, J. F., Hult, G. T., Ringle, C. M., \& Sarstedt, M. (2017). A primer on partial least squares structural equation modeling (PLS-SEM) $\left(2^{\text {nd }}\right.$ ed.). Los Angeles: Sage.

Heuvel, J. v., Gils, A. V., \& Voordeckers, W. (2006). Board Roles in small and medium-sized family businesses: Performance and importance. Corporate Governance-an International Review, 14(5), 365-517.

Hillier, D., Martinez, B., Patel, P. C., Pindado, J., \& Requejo, I. (2018). Pound of flesh? Debt contract strictness and family firms. Entrepreneurship Theory and Practice, 42(2), 259-282.

IBRD, IFC, \& MIGA. (2019). FY20-21 country engagement note for the Republic of Yemen. Yemen: World Band Group.

Janssen, A. S. (2015). Situated novelty: Introducing a process perspective on the study of innovation. Research Policy, 44(10), 1974-1984.

Jaskiewicz, P., \& Klein, S. (2007). The impact of goal alignment on board composition and board size in family businesses. Journal of Business Research, 60(10), 1080-1089.

Kellermanns, F. W., Eddleston, K. A., Barnett, T., \& Pearson, A. (2008). An exploratory study of family member characteristics and involvement: Effects on entrepreneurial behavior in the family firm. Family Business Review, $27(1), 1-14$.

Klein, S. B. (2000). Family businesses in Germany: Significance and structure. Family Business Review, 13(3), 157-172.

Knowles, C., Hansen, E., \& Dibrell, C. (2008). Measuring firm innovativeness: Development and refinement of a new scale. Journal of Forest Products Business Research, 5(5), 1-21.

Koeberle-Schmid, A., Kenyon-Rouvinez, D., \& Poza, E. J. (2014). Maximizing Success through Professional Family Business Governance. In A. KoeberleSchmid, D. Kenyon-Rouvinez, \& E. Poza (Eds.), Governance in family enterprises: Maximising economic and emotional success (pp. 3-19). Berlin, Germany: Springer 
Koładkiewicz, I. (2014). The family meeting as a mechanism of family governance: Review of the experiences of polish family companies. Central European Business Review, 22(3), 37-55.

Kreiser, P. M., Marino, L. D., \& Weaver, K. M. (2002). Assessing the psychometric properties of the entrepreneurial orientation scale: A multi-country analysis. Entrepreneurship Theory and Practice, 26(4), 71-95.

Kumar, S. (2018). Understanding different issues of unit of analysis in a business research. Journal of General Management Research, 5(2), 70-82.

Lam, A. (2004). Organizational innovation. In D. C. Fagerberg (Ed.), The Oxford Handbook of Innovation (pp. 115-147). New York: Oxford University Press.

Lam, T. Y., \& Lee, S. K. (2008). CEO duality and firm performance: Evidence from Hong Kong. The International Journal of Business in Society, 8(3), 299-316.

Leal-Rodríguez, A. L., Albort-Morant, G., \& Martelo-Landroguez, S. (2016). Links between entrepreneurial culture, innovation, and performance: The moderating role of family firms. International Entrepreneurship and Management Journal, 13(3), 819-835.

Lee, T., \& Chu, W. (2017). The relationship between entrepreneurial orientation and firm performance: Influence of family governance. Journal of Family Business Strategy, 8(4), 213-223.

Li, Z., \& Daspit, J. J. (2016). Understanding family firm innovation heterogeneity: A typology of family governance and socioemotional wealth intentions. Journal of Family Business Management, 6(2), 103-121.

Llach, J. (2010). Innovation in family and non-family businesses: a resource perspective. International Journal of Entrepreneurial Venturing, 2(3/4), 381-395.

Maseda, A., Iturralde, T., Aparicio, G., Boulkeroua, L., \& and Cooper, S. (2019). Family board ownership, generational involvement and performance in family SMEs: A test of the S-shaped hypothesis. European Journal of Management and Business Economics, 28(3), 285-300.

Massis, A. D., Kotlar, J., Frattini, F., Chrisman, J. J., \& Nordqvist, M. (2016). Family governance at work: Organizing for new product development in family SMEs. Family Business Review, 29(2), 1-25.

Massis, A., Frattini, F., \& Lichtenthaler, U. (2013). Research on technological innovation in family firms: Present debates and future directions. Family Business Review, 26(1), 10-31.

Matzler, K., Veider, V., Hautz, J., \& Stadler, C. (2015). The impact of family ownership, management, and governance on innovation. Product Innovation Management, 32(3), 319-333. 
Assoc. Prof. Dr. Murad Mohammed Abdullah Al-Nashmi Dr. Mohammed Ahmed Ali Shujaa Aldeen

Memili, E., Singal, M., \& Barrédy, C. (2016). Family governance and family firm outcomes. Journal of Family Business Management, 6(2), 1-7.

Miller, D., Breton-Miller, I. L., Amore, M. D., Minichilli, A., \& Corbetta, G. (2017). Institutional logics, family firm governance and performance. Journal of Business Venturing, 32(6), 674-693.

Minetti, R., Murro, P., \& Paiella, M. (2015). Ownership structure, governance, and innovation. European Economic Review, 80, 165-193.

Neubaver, F., \& Lank, A. G. (1998). The family business: Its governance for sustainability. London: Macmillan Press Ltd.

Pauget, B., \& Wald, A. (2018). Creating and implementing organizational innovation: The role of professional identity and network embeddedness in healthcare organizations. European Journal of Innovation Management, $27(3), 384-401$.

Pittino, D., Martínez, A. B., Chirico, F., \& Galván, R. S. (2018). Psychological ownership, knowledge sharing and entrepreneurial orientation in family firms: The moderating role of governance heterogeneity. Journal of Business Research, 84, 312-326.

Ramli, N. A., Latan, H., \& Nartea, G. V. (2018). Why should PLS-SEM be used rather than regression? Evidence from the capital structure perspective. In $\mathrm{H}$. Latan (Ed.), PLS-SEM: Recent advances in banking \& finance (pp. 171-209). Cham: Springer International.

Saidat, Z., Silva, M., \& Seaman, C. (2018). The relationship between corporate governance and financial performance: Evidence from Jordanian family and nonfamily firms. Journal of Family Business Management, 9(1), 54-78.

Saleem, I., Khalid, F., \& Nadeem, M. (2019). Family business governance: What's wrong? What's right? What's next? Emerald Emerging Markets Case Studies, 9(1), 1-23.

Sarbah, A., \& Xiao, W. (2015). Good corporate governance structures: A must for family businesses. Open Journal of Business and Management, 3(1), 40-57.

Sirmon, D. G., \& Hitt, M. A. (2003). Managing resources: Linking unique resources, management, and wealth creation in family firms. Entrepreneurship Theory and Practice, 27(4), 339-358.

Sofan, S. (January 3, 2019). Yemen's private sector teaming up to support humanitarian and recovery efforts. Retrieved May 11, 2019, from https://bit.ly/3Jd036r

Stuart, J. B. (2000). Aging, obsolescence and organizational innovation. Administrative Science Quarterly, 45(1), 81-112. 
Sua're, K. C., \& Santana-Martı'n, D. J. (2004). Governance in Spanish family business. International Journal of Entrepreneurial Behavior \& Research, $10(1 / 2), 141-163$.

Suess, J. (2014). Family governance - Literature review and the development of a conceptual model. Journal of Family Business Strategy, 5(2), 138-155.

Tagiuri, R., \& Davis, J. A. (1992). On the goal of successful family companies. Family Business Review, 5(1), 43-62.

Uhlaner, L. M. (2006). Business family as a team: Underlying force for sustained competitive advantage. In P. Z. Poutziouris, K. X. Smyrnios, \& S. B. Klein (Eds.), Handbook of research on family business (pp. 125-144). Glos: Edward Elgar Publishing Limited.

Wilson, N., Wright, M., \& Scholes, L. (2013). Family business survival and the role of boards. Entrepreneurship Theory and Practice, 37(6), 1369-1389.

Yemen Business Club (YBC). (December 29, 2016b). Second conference of family firms. Retrieved March 8, 2019, from YBC: www.ybc-yemen.com

Yemen Business Club (YBC). (January 14, 2016a). First conference of family firms. Retrieved March 8, 2019, from Yemen Business Club: https://www.ybc-yemen.com 